\title{
Factors associated with in-hospital mortality in adult sepsis with Escherichia coli infection
}

\author{
Kun Song ${ }^{\dagger}$, Cuirong Guo ${ }^{\dagger}$, Zhao Zeng ${ }^{\dagger}$, Changluo Li and Ning Ding ${ }^{*}$ (i)
}

\begin{abstract}
Background: Escherichia coli (E. coli) is an important pathogen in sepsis. This study aimed to explore the factors which were associated with in-hospital mortality in adult sepsis with E. coli infection based on a public database.

Methods: All sepsis patients with E. coli infection in MIMIC-III were included in this study. Clinical characteristics between the survivor and non-survivor groups were analyzed. Factors associated with in-hospital mortality were identified by multivariate logistic regression.
\end{abstract}

Results: A total of 199 patients were eventually included and divided into two groups: a survivor group $(n=167)$ and a non-survivor group $(n=32)$. RDW and HCT were identified as the factors with clinical outcomes. The area under the ROC curve (AUC) were 0.633 and 0.579 , respectively. When combined RDW and HCT for predicting in-hospital mortality, the AUC was 0.772 , which was significantly superior to SOFA and APACHEll scores.

Conclusion: RDW and HCT were identified as factors associated with in-hospital mortality in adult sepsis patients with E. coli infection. Our findings will be of help in early and effective evaluation of clinical outcomes in those patients.

Keywords: RDW, HCT, Sepsis, E. coli, Prognosis

\section{Introduction}

Sepsis has been defined as a dysregulated host immune response to infections, leading to a life-threatening organ dysfunction [1]. Escherichia coli (E. coli) as one major kind of gram-negative bacilli may cause intra-abdominal infections, urinary tract infections, and sepsis [2]. An early-onset neonatal sepsis research with 235 cases showed that the most frequent pathogen was E. coli $(86$ [36.6\%]) with higher incidence of mortality [3]. In China, a recent study clarified that $E$. coli infection accounted for nearly $30 \%$ in neonatal sepsis with more than a $10 \%$ death rate [4]. The immature immune systems of neonates may lead to a higher mortality in $E$. coli infection. Hence, early identification of those sepsis patients with poor prognosis was significant.

However, for E. coli infection, most previous studies focused on neonatal sepsis and few studies have been done for investigating the clinical characteristics of adult patients. Moreover, little has been known about the predictive values of different laboratory variables in adult sepsis with E. coli infection. Therefore, in our study, we aimed to explore the factors which were associated with in-hospital mortality in adult sepsis with $E$. coli infection based on a public database.

\section{Methods}

\section{Patients}

All sepsis patients with E. coli infection in MIMICIII were included in this study. MIMIC-III database as an US-based critical care public database includes data linked with 53,423 adult patients (aged 16 years

\footnotetext{
†'Kun Song, Cuirong Guo and Zhao Zeng contributed equally to this article

Department of Emergency Medicine, The Affiliated Changsha Central Hospital, Hengyang Medical School, University of South China, NO.161 Shaoshan South Road, Changsha 410004, Hunan, China

*Correspondence: doctordingning@csu.edu.cn; doctordingning@sina.com
}

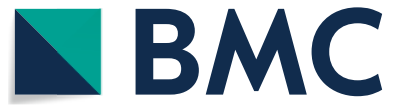

(c) The Author(s) 2022. Open Access This article is licensed under a Creative Commons Attribution 4.0 International License, which permits use, sharing, adaptation, distribution and reproduction in any medium or format, as long as you give appropriate credit to the original author(s) and the source, provide a link to the Creative Commons licence, and indicate if changes were made. The images or other third party material in this article are included in the article's Creative Commons licence, unless indicated otherwise in a credit line to the material. If material is not included in the article's Creative Commons licence and your intended use is not permitted by statutory regulation or exceeds the permitted use, you will need to obtain permission directly from the copyright holder. To view a copy of this licence, visit http://creativecommons.org/licenses/by/4.0/. The Creative Commons Public Domain Dedication waiver (http://creativeco mmons.org/publicdomain/zero/1.0/) applies to the data made available in this article, unless otherwise stated in a credit line to the data. 
or above) from 2001 to 2012 and 7870 neonates from 2001 to 2008 admitted to a intensive care unit (ICU) [5]. Data including vital signs, medications, laboratory measurements, observations and notes charted by care providers, fluid balance, procedure codes, diagnostic codes, imaging reports, hospital length of stay and survival data were comprehensively recorded. The following tables in MIMIC III dataset were utilized in our study: ADMISSIONS, CHARTEVENTS, D_ICD DIAGNOSIS, D_ITEMS, D_LABIEVENTS, DIAGNOSIS_ICD, ICUSTAYS, LABEVENTS, NOTEEVENTS, PATIENTS, INPUTEVENTS_CV, INPUTEVENTS _ MV and OUTPUTEVENTS [5].

\section{Study population}

All patients with a diagnosis relevant to sepsis with $E$. coli infection in the database were initially screened. The diagnosis of sepsis with $E$. coli infection in the database was confirmed by the lab findings when the pathogen culture in blood was positive in E. coli. Only the data of each patient in the first admission were utilized in this study. Exclusion criteria included as follows: patients with missing $>5 \%$ individual data and age less than 18.

\section{Data extraction}

Data extraction was performed by using structure query language (SQL). The data of demographic characteristics, clinical variables, laboratory variables and scoring systems were extracted for further analysis. The baseline characteristics used were those recorded within $24 \mathrm{~h}$ after admission. When one variable was recorded at a different time compared to the initial $24 \mathrm{~h}$, the first one was enrolled in the study. Demographic characteristics included age, gender, marital status, ethnicity, ICU department, admission type, and comorbidities (renal disease, coronary artery disease (CAD), diabetes, hypertension). Clinical and laboratory variables included systolic blood pressure (SBP), diastolic blood pressure (DBP), heart rate (HR), respiratory rate (RR), white blood cells (WBC), neutrophils, lymphocytes, basophils, platelet (PLT), red cell volume distribution width (RDW), hematocrit (HCT), glucose, prothrombin time (PT), thrombin time (TT), albumin, alanine aminotransferase (ALT), aspartate aminotransferase (AST), mean corpuscular volume $(\mathrm{MCV})$, total bilirubin, creatinine, lactate, total calcium and anion gap. Clinical outcomes including length of stay (LOS) in ICU and in-hospital mortality and scoring systems including sequential organ failure assessment (SOFA) and acute physiology and chronic health evaluation (APACHEII) were also extracted.

\section{Statistical analysis}

Characteristics are expressed as mean \pm standard deviation or median (IQR) for continuous variables and a percentage or frequency for categorical variables. Continuous variables were compared using Student's t-test (normal distribution) or Mann-Whitney U-test (Skewed distribution), and categorical variables were compared using Fisher's exact test or Chi-square analysis. Stepwise logistic regression for variables selection in multivariable logistic regression was performed. Variables with $\mathrm{P}<0.2$ which were compared between the survivor and non-survivor groups were further enrolled in multivariable logistic regression. Then, factors associated with in-hospital mortality was identified by multivariate logistic regression. Finally, the receiver-operator characteristic (ROC) analysis of different factors for predicting in-hospital mortality were performed. The cut-off values of variables were confirmed by the Youden Index (sensitivity + specificity-1). The value of each variable with the maximum Youden Index was the cut-off value.

SPSS software (version 26) was implemented for statistical analysis. Two-sided $\mathrm{P}$ values $<0.05$ were considered statistically significant.

\section{Results}

\section{General characteristics of the patients}

At first, 5403 sepsis patients were included. Then, based on the infection of different pathogens, 210 sepsis patients with $E$. coli infection were enrolled in this research. According to the exclusion criteria, 11 patients were excluded and a total of 199 patients were included and divided into a survivor group $(\mathrm{n}=167)$ and a nonsurvivor group ( $\mathrm{n}=32)$ (Fig. 1). General characteristics of the cohort were elucidated in Table 1 . The median age was 69.52 and males accounted for $45.22 \%$ in total. Most of the patients were hospitalized in MICU $(83.42 \%)$ and emergency admission was the most common admission type (96.98\%). The top four comorbidities were as follows: hypertension (45.73\%), CAD (18.09\%), diabetes $(4.52 \%)$ and renal disease $(4.02 \%)$. The median scores of APACHEII and SOFA were 14 and 3 , respectively.

The median days of LOS in ICU and in hospital were 3.7 and 8 , respectively. In-hospital mortality was $16.08 \%$.

\section{Comparison of variables between survivor and non-survivor groups}

Different variables in survivor and non-survivor groups were compared and analyzed in Table 2 . The median age of the survivor and non-survivor groups were 69.96 and $68.32(\mathrm{P}=0.573)$. Gender showed no significant difference $(P=0.171)$. In vital signs, no significant differences showed in DBP $(\mathrm{P}=0.414)$, SBP $(\mathrm{P}=0.138)$ and $\mathrm{RR}$ 
All sepsis patients in the database $(n=5403)$

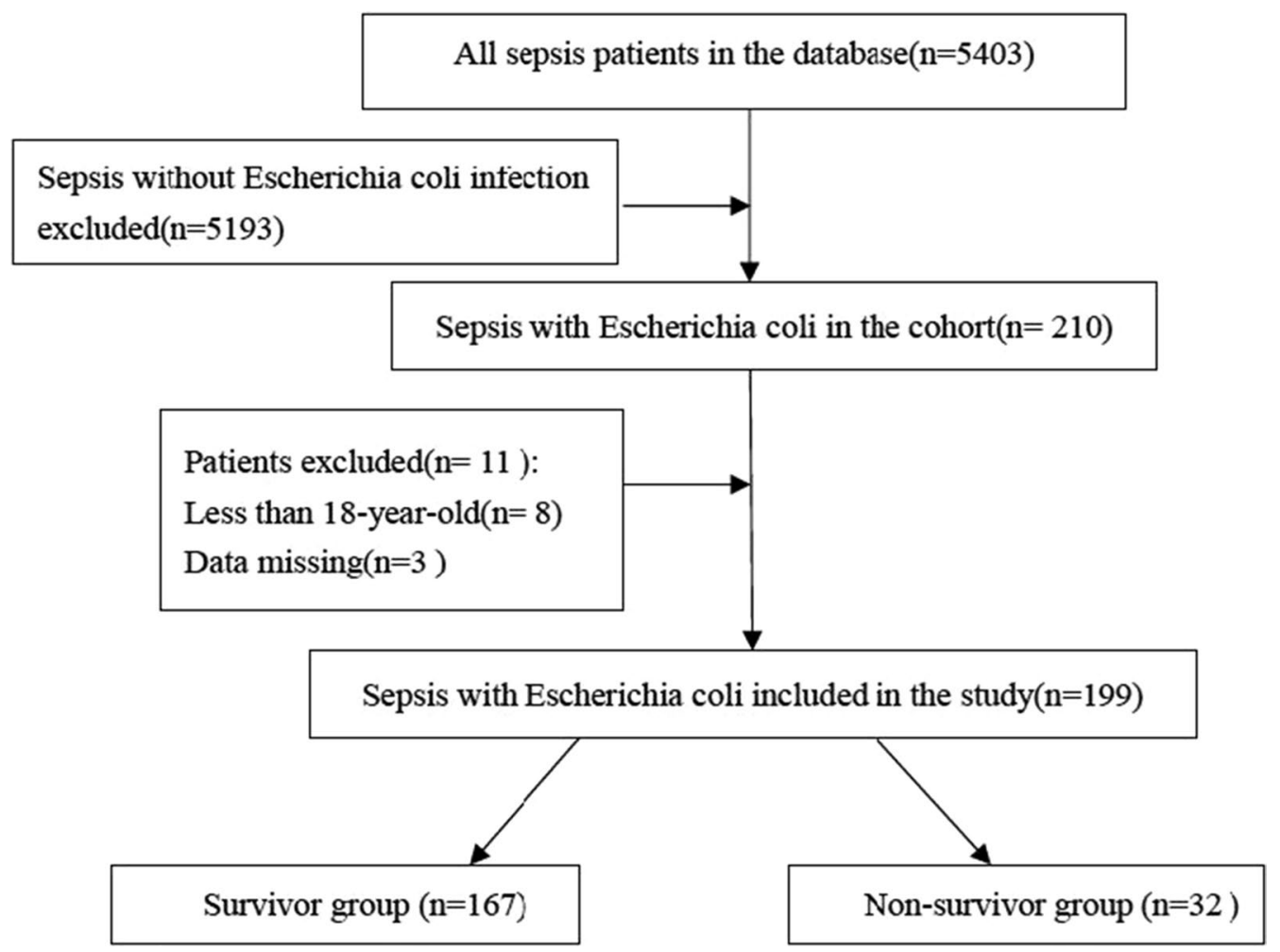

Fig. 1 Flow chart for patients enrollment and study design

$(P=0.068)$, while $H R$ was significantly higher in the nonsurvivor group $(\mathrm{P}=0.043)$. Comparison of comorbidities including renal disease $(\mathrm{P}=0.778), \mathrm{CAD}(\mathrm{P}=0.916)$, hypertension $(\mathrm{P}=0.149)$ and diabetes $(\mathrm{P}=0.806)$ demonstrated no significant differences between the two groups. In laboratory characteristics, PLT $(\mathrm{P}=0.551)$, AST $(P=0.863), \operatorname{MCV}(P=0.278)$ glucose $(P=0.475)$, ALT $(P=0.789)$, TT $(P=0.733)$, hematocrit $(P=0.060)$, PT $(\mathrm{P}=0.935)$, anion gap $(\mathrm{P}=0.273)$, lymphocytes $(\mathrm{P}=0.590)$, WBC $(\mathrm{P}=0.479)$, lactate $(\mathrm{P}=0.078)$, albumin $(P=0.369)$, creatinine $(P=0.728)$, total bilirubin $(P=0.176)$ and calcium $(P=0.854)$ didn't have any significant differences between the two groups. Neutrophils $(\mathrm{P}=0.015)$, RDW $(\mathrm{P}=0.026)$ and basophils $(\mathrm{P}=0.021)$ showed significant differences. There was no significant difference in the scores of APACHEII $(\mathrm{P}=0.585)$ and SOFA $(P=0.357)$. In the non-survivor group, the days of LOS in ICU $(\mathrm{P}<0.001)$ and hospital $(\mathrm{P}=0.032)$ were longer.

\section{Factors associated with in-hospital mortality} in multivariable analysis

Variables including gender (male), SBP, HR, RR, diabetes, neutrophils, HCT, RDW, lactate, total bilirubin and basophils were enrolled in multivariable analysis (Table 3 ).
Two factors associated with in-hospital mortality were identified: HCT $(\mathrm{P}=0.007$, Odds Ratio $(\mathrm{OR})=1.116$, $95 \% \mathrm{CI}=1.030-1.209)$ and $\mathrm{RDW}(\mathrm{P}=0.002, \mathrm{OR}=1.435$, $95 \% \mathrm{CI}=1.140-1.806)$.

\section{Predictive performances of factors and scoring systems}

In Table 4 and Fig. 2, different predictive performances of HCT, RDW and scoring systems including SOFA and APAHEII were demonstrated. The cut-off values of RDW and HCT were $15.45 \%$ and $38.4 \%$, respectively. The area under the ROC curve (AUC) of RDW and HCT were 0.633 and 0.579 , respectively. When combined RDW and HCT for predicting in-hospital mortality, the AUC was 0.772 , which was significantly superior to SOFA and APACHEII scores.

\section{Discussion}

In our retrospective study, RDW and HCT were identified as factors associated with in-hospital mortality in adult sepsis patients with $E$. coli infection. To the best of our knowledge, this was the first study to explore the association of the factors with clinical prognosis in adult sepsis with $E$. coli infection based on MIMIC-III public database. 
Table 1 General characteristics of the patients

\begin{tabular}{|c|c|}
\hline \multicolumn{2}{|l|}{ Variables } \\
\hline Number of patients (n) & 199 \\
\hline Age (years) & $69.52(61.01-82.35)$ \\
\hline \multicolumn{2}{|l|}{ Gender (n, \%) } \\
\hline Male & $90(45.22 \%)$ \\
\hline Female & $109(54.78 \%)$ \\
\hline \multicolumn{2}{|l|}{ Marital status (n, \%) } \\
\hline Divorced & $14(7.03 \%)$ \\
\hline Married & $83(41.72 \%)$ \\
\hline Single & $58(29.14 \%)$ \\
\hline Widow & $33(16.58 \%)$ \\
\hline Others & $11(5.53 \%)$ \\
\hline \multicolumn{2}{|l|}{ Ethnicity (n, \%) } \\
\hline Asian & $14(7.04 \%)$ \\
\hline White & $142(71.36 \%)$ \\
\hline Black/American & $14(7.03 \%)$ \\
\hline Hispanic/Latino & $4(2.01 \%)$ \\
\hline Others & $25(12.56 \%)$ \\
\hline \multicolumn{2}{|l|}{ Department $(n, \%)$} \\
\hline $\mathrm{CCU}$ & $12(6.03 \%)$ \\
\hline MICU & $166(83.42 \%)$ \\
\hline SICU & $12(6.03 \%)$ \\
\hline TICU & $5(2.51 \%)$ \\
\hline CSRU & $4(2.01 \%)$ \\
\hline \multicolumn{2}{|l|}{ Admission type $(n, \%)$} \\
\hline Elective & $4(2.01 \%)$ \\
\hline Urgent & $2(1.01 \%)$ \\
\hline Emergency & 193 (96.98\%) \\
\hline \multicolumn{2}{|l|}{ Comorbidities (n, \%) } \\
\hline Renal disease & $8(4.02 \%)$ \\
\hline$C A D$ & $36(18.09 \%)$ \\
\hline Diabetes & $9(4.52 \%)$ \\
\hline Hypertension & 91 (45.73\%) \\
\hline \multicolumn{2}{|l|}{ Scoring system } \\
\hline APACHEII & $14(12-17)$ \\
\hline SOFA & $3(1-4)$ \\
\hline \multicolumn{2}{|l|}{ Clinical outcomes } \\
\hline LOS in ICU (days) & $3.70(1.96-8.97)$ \\
\hline LOS in hospital (days) & $8(5-17)$ \\
\hline In-hospital mortality (n, \%) & $32(16.08 \%)$ \\
\hline
\end{tabular}

SOFA sequential organ failure assessment, APACHE acute physiology and chronic health evaluation, LOS length of stay, ICU intensive care unit, CAD coronary artery disease

RDW as a parameter which could measure the range of variation of red blood cell size has been proved to be a common and inexpensive biomarker in critical illness [6]. Elevated RDW levels implicated higher variation in size, which has been usually applied for differentiation in anemia due to nutritional deficiency [7].
There is an accumulation of studies that have explored the association between RDW and clinical outcomes in sepsis. Recently, two modified and simple scores both including RDW have been proved to be useful tools for predicting short-term outcomes in sepsis or septic shock $[8,9]$. One study focusing on neonatal sepsis elucidated that RDW to platelet ratio as a useful systemic inflammatory marker could be an indicator for sepsis occurrence in early stage [10]. In adult sepsis patients, the combination of three parameters including RDW, platelet distribution width and the neutrophil-lymphocyte count ratio which were easily acquired from whole blood cell count analysis had a good diagnostic performance [11]. A nomogram including RDW provided a relatively accurate prediction for the early identification of septic patients at high risk of mortality in the emergency department [12]. One meta-analysis including 17,961 sepsis patients from 11 studies demonstrated that RDW was a significantly useful predictor of mortality in sepsis and patients with elevated RDW were more likely to have higher mortality [13].

Studies on RDW in different cohorts had different cutoff values. In a study with a total of 103 patients with community-acquired intra-abdominal sepsis, $R D W \geq 16$ had an AUC of 0.867 for predicting in-hospital mortality [14]. Another study with 1046 patients concluded that for 30-day mortality and early clinical deterioration, an optimal cut-off value of RDW were 12.95 and 14.48 , respectively [15]. One recent study on sepsis patients demonstrated that Youden Index was maximum (37\%) at RDW value 14.75 , which was good at predicting mortality within 28-days of emergency admission [16]. In our study, the best threshold value of RDW for predicting inhospital mortality was 15.45 .

The underlying mechanisms as to why increased RDW was associated with adverse prognosis in sepsis remained largely unknown, but several explanations have been illuminated in some studies. First, elevated inflammatory markers due to systemic inflammation response in sepsis may affect the erythrocytes maturation and lead to the migration of reticulocytes into the peripheral circulation, thereby resulting in RDW being elevated [17]. Second, reactive erythropoiesis was stimulated under oxidative stress which was one of the pathophysiologic entities of sepsis. Then, large immature red cells with poor oxygenbinding capacity were released, causing an increase in the RDW [18]. Third, sepsis can interrupt the iron steady state, trigger bone marrow suppression, and downregulate the expression of the erythropoietin receptor, which all contribute and cause more production of ineffective red blood cell and RDW increased [19].

In our research, HCT was another factor which was associated with in-hospital mortality in sepsis. One 
Table 2 Comparison of variables between survivor and non-survivor groups

\begin{tabular}{|c|c|c|c|}
\hline Variables & Survivor $(n=167)$ & Non-survivor $(n=32)$ & P-value \\
\hline Age (years) & $69.96 \pm 14.80$ & $68.32 \pm 16.04$ & 0.573 \\
\hline \multicolumn{4}{|l|}{ Gender (n, \%) } \\
\hline Male & $72(43.11 \%)$ & $18(56.25 \%)$ & \multirow[t]{2}{*}{0.171} \\
\hline Female & $95(56.89 \%)$ & $14(43.75 \%)$ & \\
\hline \multicolumn{4}{|l|}{ Vital signs } \\
\hline $\mathrm{DBP}(\mathrm{mmHg})$ & $59.00(48.50,71.50)$ & $63.00(52.00,69.00)$ & 0.414 \\
\hline $\mathrm{SBP}(\mathrm{mmHg})$ & $110.83 \pm 24.586$ & $117.84 \pm 23.489$ & 0.138 \\
\hline HR (beats/min) & $97.46 \pm 19.739$ & $105.22 \pm 19.511$ & 0.043 \\
\hline RR (beats/min) & $20.00(16.00,25.00)$ & $22.50(20,28.75)$ & 0.068 \\
\hline \multicolumn{4}{|l|}{ Comorbidities (n,\%) } \\
\hline Renal disease & $7(4.19 \%)$ & $1(3.12 \%)$ & 0.778 \\
\hline$C A D$ & $30(17.96 \%)$ & $6(18.75 \%)$ & 0.916 \\
\hline Diabetes & $6(3.59 \%)$ & $3(9.37 \%)$ & 0.149 \\
\hline Hypertension & $77(46.11 \%)$ & $14(43.75 \%)$ & 0.806 \\
\hline \multicolumn{4}{|l|}{ Laboratory characteristics } \\
\hline $\operatorname{PLT}\left({ }^{*} 10^{9} / \mathrm{L}\right)$ & $189.00(132.50,295.00)$ & $198.00(125.00,310.00)$ & 0.551 \\
\hline AST (IU/L) & $47.00(25.50,90.00)$ & $48.00(26.00,92.00)$ & 0.863 \\
\hline$M C V(f L)$ & $91.00(88.00,96.00)$ & $91(87.50,95.00)$ & 0.278 \\
\hline Glucose (mg/dL) & $121.00(103.50,163.50)$ & $138.00(116.00,166.00)$ & 0.475 \\
\hline ALT (IU/L) & $33.00(19.50,85.00)$ & $38.00(17.00,54.00)$ & 0.789 \\
\hline Neutrophils (\%) & $78.50(66.50,82.50)$ & $82.00(75.00,89.90)$ & 0.015 \\
\hline $\mathrm{TT}(\mathrm{s})$ & $30.40(26.35,35.40)$ & $32.70(27.70,39.50)$ & 0.733 \\
\hline $\mathrm{HCT}(\%)$ & $34.16 \pm 5.41$ & $36.43 \pm 8.28$ & 0.060 \\
\hline PT (s) & $14.40(13.15,17.30)$ & $14.90(12.80,19.40)$ & 0.935 \\
\hline Anion Gap (mmol/L) & $17.00(13.00,20.00)$ & $17.00(13.00,21.00)$ & 0.273 \\
\hline RDW (\%) & $14.87 \pm 1.85$ & $15.70 \pm 2.18$ & 0.026 \\
\hline Lymphocytes (\%) & $6.00(2.95,12.00)$ & $8.00(5.00,15.00)$ & 0.590 \\
\hline WBC $\left({ }^{*} 10^{9} / L\right)$ & $12.20(6.30,19.75)$ & $13.50(3.70,18.30)$ & 0.479 \\
\hline Lactate (mmol/L) & $2.40(1.45,3.45)$ & $2.90(1.60,4.50)$ & 0.078 \\
\hline Albumin (g/dL) & $3.00(2.50,3.50)$ & $2.90(2.50,3.40)$ & 0.369 \\
\hline Creatinine $(\mathrm{mg} / \mathrm{dL})$ & $1.30(1.00,2.150$ & $1.40(0.90,2.50)$ & 0.728 \\
\hline Total bilirubin (mg/dL) & $0.80(0.40,1.60)$ & $1.10(0.50,3.70)$ & 0.176 \\
\hline Total calcium (mg/dL) & $8.02 \pm 0.964$ & $7.99 \pm 1.383$ & 0.854 \\
\hline Basophils (\%) & $0.00(0.00,0.20)$ & $0.00(0.00,0.10)$ & 0.021 \\
\hline \multicolumn{4}{|l|}{ Scoring system (IQR) } \\
\hline APACHEII & $14.00(12.00,18.00)$ & $15.50(10.50,17.00)$ & 0.585 \\
\hline SOFA & $2.00(1.00,4.00)$ & $3.00(2.00,4.75)$ & 0.357 \\
\hline \multicolumn{4}{|l|}{ Clinical outcomes (days) } \\
\hline LOS in ICU & $3.22(1.87,7.82)$ & $11.01(4.66,17.75)$ & $<0.001$ \\
\hline LOS in hospital & $8.00(5.00,15.00)$ & $13.50(6.25,35.50)$ & 0.032 \\
\hline
\end{tabular}

$S B P$ systolic blood pressure, $D B P$ diastolic blood pressure, $H R$ heart rate, $R R$ respiratory rate, $C A D$ coronary artery disease, $W B C$ white blood cells, $P L T$ platelet, $R D W$ red cell volume distribution width, $P T$ prothrombin time, $T T$ thrombin time, $A L T$ alanine aminotransferase, $A S T$ aspartate aminotransferase, $H C T$ hematocrit, $M C V$ mean corpuscular volume, SOFA sequential organ failure assessment, APACHE acute physiology and chronic health evaluation, $L O S$ length of stay, ICU intensive care unit, IQR interquartile ranges

recent study based on machine learning for early detection of late-onset neonatal sepsis showed that HCT was one of top three predictive variables [20]. Another study in Brazil found that as a predictor of mortality risk in the sepsis, the level of HCT decreased with worse outcomes
[21]. However, a positive relationship between HCT and mortality was found in our study, which was not consistent with some previous studies [22, 23]. The differences could be partly explained by two reasons. First, sepsis patients with poor outcomes were more likely to be 
Table 3 Factors associated with in-hospital mortality in multivariable analysis

\begin{tabular}{|c|c|c|c|c|c|c|c|}
\hline \multirow[t]{2}{*}{ Variables } & \multirow[t]{2}{*}{ B } & \multirow[t]{2}{*}{ SE } & \multirow[t]{2}{*}{ Wald } & \multirow[t]{2}{*}{$P$ value } & \multirow[t]{2}{*}{ OR } & \multicolumn{2}{|c|}{$95 \% \mathrm{Cl}$ for OR } \\
\hline & & & & & & Lower & Upper \\
\hline Male & 0.406 & 0.464 & 0.764 & 0.382 & 1.500 & 0.604 & 3.727 \\
\hline SBP & 0.008 & 0.010 & 0.654 & 0.419 & 1.008 & 0.989 & 1.027 \\
\hline$H R$ & 0.004 & 0.013 & 0.087 & 0.768 & 1.004 & 0.978 & 1.031 \\
\hline RR & 0.060 & 0.040 & 2.249 & 0.134 & 1.062 & 0.982 & 1.149 \\
\hline Diabetes & 1.527 & 0.942 & 2.625 & 0.105 & 4.603 & 0.726 & 29.174 \\
\hline Neutrophils & -0.023 & 0.011 & 4.017 & 0.055 & 0.978 & 0.956 & 1.018 \\
\hline $\mathrm{HCT}$ & 0.110 & 0.041 & 7.227 & 0.007 & 1.116 & 1.030 & 1.209 \\
\hline RDW & 0.361 & 0.117 & 9.459 & 0.002 & 1.435 & 1.140 & 1.806 \\
\hline Lactate & 0.024 & 0.124 & 0.036 & 0.849 & 1.024 & 0.804 & 1.305 \\
\hline Total Bilirubin & 0.059 & 0.052 & 1.321 & 0.250 & 1.061 & 0.959 & 1.174 \\
\hline Basophils & -0.672 & 0.814 & 0.682 & 0.409 & 0.511 & 0.104 & 2.517 \\
\hline
\end{tabular}

$C l$ confidential interval, $O R$ odds ratio, $R D W$ red cell volume distribution width, SBP systolic blood pressure, $H R$ heart rate, $R R$ respiratory rate, $H C T$ hematocrit

Table 4 Predictive performances of RDW, HCT and scoring systems

\begin{tabular}{llllcr}
\hline Variables & AUC & $\mathbf{9 5 \% C l}$ & Cut-off value & Sensitivity (95\%Cl) & Specificity (95\%Cl) \\
\hline RDW (\%) & 0.633 & $0.518-0.748$ & 15.45 & $0.625(0.437-0.783)$ & $0.686(0.611-0.756)$ \\
HCT (\%) & 0.579 & $0.451-0.706$ & 38.4 & $0.438(0.268-0.621)$ & $0.801(0.732-0.858)$ \\
RDW + HCT & 0.772 & $0.687-0.858$ & - & - & - \\
SOFA & 0.550 & $0.441-0.658$ & 3 & $0.613(0.407-0.757)$ & $0.487(0.425-0.580)$ \\
APACHEII & 0.539 & $0.427-0.651$ & 14 & $0.613(0.408-0.758)$ & $0.573(0.502-0.655)$ \\
\hline
\end{tabular}

AUC area under the ROC curve, $\mathrm{Cl}$ confidential interval, SOFA sequential organ failure assessment, $A P A C H E$ acute physiology and chronic health evaluation, $R D W$ red cell volume distribution width, $\mathrm{HCT}$ hematocrit

suffering from hypovolemia due to increased capillary permeability [24], which resulted in higher levels of HCT. Second, the general characteristics of sepsis patients in different studies were not the same.

Limitations should also be clarified in our study. First, the study was on the basis of a publicly singlecenter database in US. While applying to other nations, concerns regarding the generalizability of the conclusions and the confounding bias caused by the missing data should be considered. Second, the new definition of Sepsis-3 was not included in this study because the patients in MIMIC-III were enrolled before 2012, which may lead to some limitations in applying our results. Third, RDW is always related to the underlying condition, especially chronic anemia, while anemia is one of the most common complications in patients with sepsis in the ICU [25]. Sepsis-related anemia can be caused by some factors including fluid loading-related hemodilution, iatrogenic blood loss, and inflammation-associated abnormalities in erythropoiesis [26, 27]. Due to lack of some data in MIMIC-III, the anemia which involved past medical history or caused by sepsis couldn't be defined clearly. Further research should be done for exploring the differences between sepsis with anemia and without anemia in order to validate our results. Fourth, samples in our study were relatively small and subgroups were not divided for further analysis. Due to lack of some data in MIMIC-III, not all the variables which may affect the association between RDW and prognosis were enrolled. Hence, more samples with more variables and multiple centers should be explored for validating our results.

\section{Conclusion}

RDW and HCT were identified as factors associated with in-hospital mortality in adult sepsis with E. coli infection. Our findings will be of help in early and effective evaluation of clinical outcomes in those patients. Therefore, the measurements of RDW and HCT should be considered for prognostic assessment of adult sepsis with E. coli infection.

\section{Abbreviations}

E. coli: Escherichia coli; SOFA: Sequential organ failure assessment; APACHE: Acute physiology and chronic health evaluation; LOS: Length of stay; ICU: Intensive care unit; CAD: Coronary artery disease; SBP: Systolic blood pressure; DBP: Diastolic blood pressure; HR: Heart rate; RR: Respiratory rate; WBC: White blood cells; PLT: Platelet; RDW: Red cell volume distribution width; PT: 


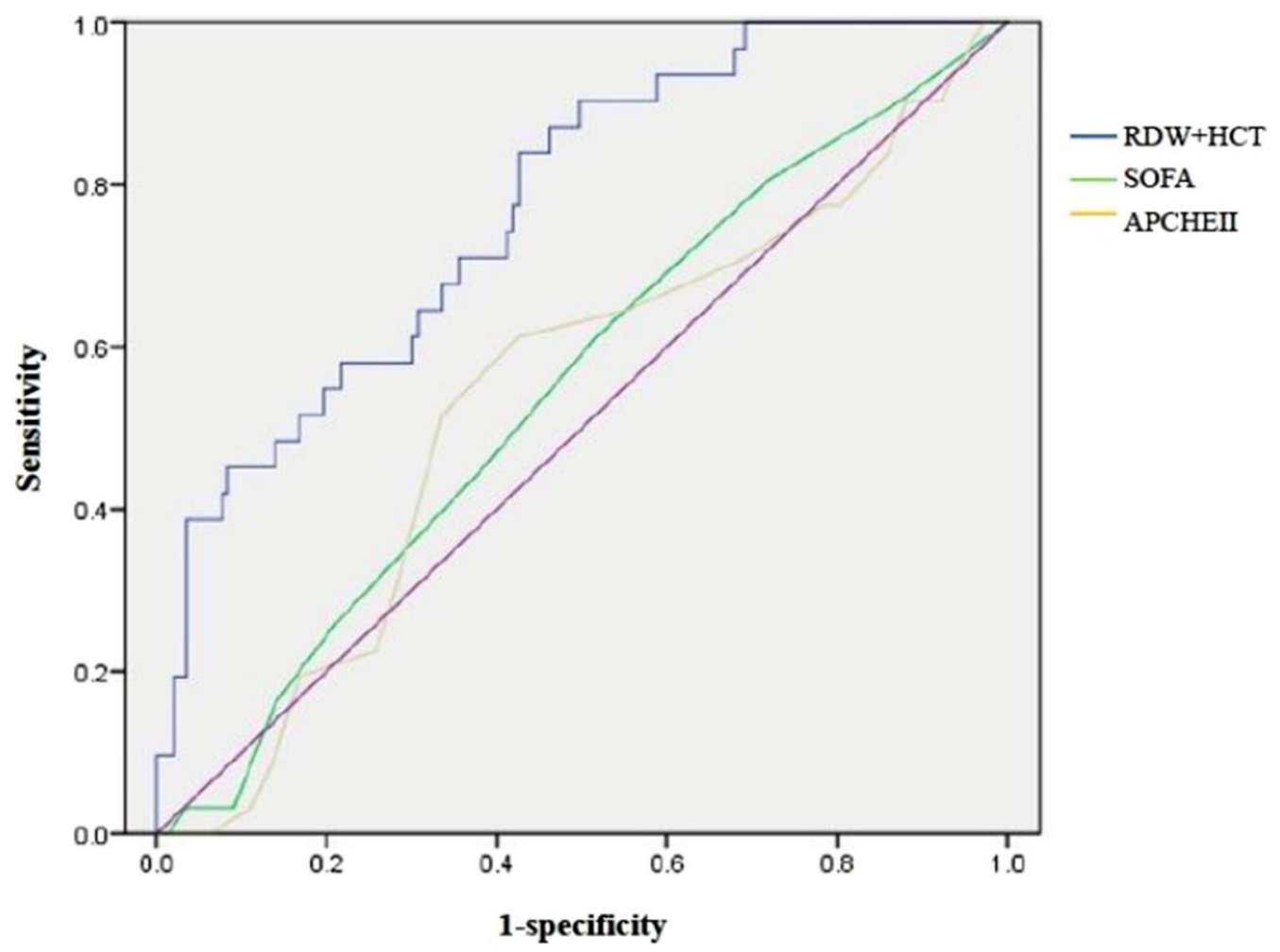

Fig. 2 ROCs of different models. SOFA sequential organ failure assessment, APACHE acute physiology and chronic health evaluation, RDW red cell volume distribution width, HCT hematocrit

Prothrombin time; TT: Thrombin time; ALT: Alanine aminotransferase; AST: Aspartate aminotransferase; HCT: Hematocrit; MCV: Mean corpuscular volume; LOS: Length of stay; ICU: Intensive care unit; IQR: Interquartile ranges; CI: Confidential interval; OR: Odds ratio; AUC: Area under the curve; ROC: Receiveroperator characteristic.

\section{Acknowledgements}

None.

\section{Authors' contributions}

Conception and design: KS, ND, ZZ. Administrative support: CL, ND. Provision of study materials or patients: ZZ, ND. Collection and assembly of data: KS, CG, ZZ. Data analysis and interpretation: KS, CG, ND. Manuscript writing: ND. All authors read and approved the final manuscript.

\section{Funding}

None.

\section{Availability of data and materials}

The data that support the findings of this study are available from the Massachusetts Institute of Technology (MIT) and Beth Israel Deaconess Medical Center (BIDMC) but restrictions apply to the availability of these data, which were used under license for the current study, and so are not publicly available. Data are however available from the authors upon reasonable request and with permission of the Massachusetts Institute of Technology (MIT) and Beth Israel Deaconess Medical Center (BIDMC).

\section{Declarations}

Ethics approval and consent to participate

This study was conducted in accordance with Good Clinical Practice (Declaration of Helsinki 2002). MIMIC-III was an anonymized public database. To apply for access to the database, we passed the Protecting Human Research Participants exam (No. 32900964). The project was approved by the institutional review boards of the Massachusetts Institute of Technology (MIT) and Beth Israel Deaconess Medical Center (BIDMC) and was given a waiver of informed consent.

\section{Consent for publication}

Not applicable.

\section{Competing interests \\ None.}

Received: 30 November 2021 Accepted: 22 February 2022

Published online: 28 February 2022

\section{References}

1. Rhodes A, Evans LE, Alhazzani W, Levy MM, Antonelli M, Ferrer R, Kumar A, Sevransky JE, Sprung CL, Nunnally ME, et al. Surviving Sepsis Campaign: International Guidelines for Management of Sepsis and Septic Shock: 2016. Intensive Care Med. 2017;43(3):304-77.

2. Ku NS, Kim HW, Oh HJ, Kim YC, Kim MH, Song JE, Oh DH, Ahn JY, Kim $\mathrm{SB}$, Jeong SJ, et al. Red blood cell distribution width is an independent predictor of mortality in patients with gram-negative bacteremia. Shock. 2012;38(2):123-7.

3. Stoll BJ, Puopolo KM, Hansen NI, Sanchez PJ, Bell EF, Carlo WA, Cotten CM, D'Angio CT, Kazzi SNJ, Poindexter BB, et al. Early-Onset Neonatal Sepsis 2015 to 2017, the Rise of Escherichia coli, and the Need for Novel Prevention Strategies. JAMA Pediatr. 2020;174(7):e200593. 
4. Zhu M, Jin Y, Duan Y, He M, Lin Z, Lin J. Multi-Drug Resistant Escherichia coli causing early-onset neonatal sepsis - a single center experience from China. Infect Drug Resist. 2019;12:3695-702.

5. Johnson AEW, Pollard TJ, Shen L, Lehman LWH, Feng ML, Ghassemi M, Moody B, Szolovits P, Celi LA, Mark RG. MIMIC-III, a freely accessible critical care database. Scientific Data. 2016;3:89.

6. Chi T, Zhao Q, Wang P. Risk factors for acute coronary syndrome in upper gastrointestinal bleeding patients. Gastroenterol Res Pract. 2021:2021:8816805.

7. Hoffmann J, Urrechaga E. Role of RDW in mathematical formulas aiding the differential diagnosis of microcytic anemia. Scand J Clin Lab Invest. 2020;80(6):464-9.

8. Kim YC, Song JE, Kim EJ, Choi H, Jeong WY, Jung IY, Jeong SJ, Ku NS, Choi JY, Song YG, et al. A simple scoring system using the red blood cell distribution width, delta neutrophil index, and platelet count to predict mortality in patients with severe sepsis and septic shock. J Intensive Care Med. 2019;34(2):133-9.

9. Kim J, Lee Y, Cho Y, Sohn Y, Hyun J, Ahn S, Lee W, Seong H, Kim J, Ahn J, et al. A modified simple scoring system using the red blood cell distribution width, delta neutrophil index, and mean platelet volume-to-platelet count to predict 28-day mortality in patients with sepsis. J Intensive Care Medicine. 2020;88506662:0933245.

10. Karabulut B, Arcagok BC. New diagnostic possibilities for early onset neonatal sepsis: red cell distribution width to platelet ratio. Fetal Pediatr Pathol. 2020;39(4):297-306.

11. Zhang HB, Chen J, Lan QF, Ma XJ, Zhang SY. Diagnostic values of red cell distribution width, platelet distribution width and neutrophil-lymphocyte count ratio for sepsis. Exp Ther Med. 2016;12(4):2215-9.

12. Zhao $C$, Wei $Y$, Chen $D$, Jin J, Chen H. Prognostic value of an inflammatory biomarker-based clinical algorithm in septic patients in the emergency department: An observational study. Int Immunopharmacol. 2020:80:106145.

13. Zhang L, Yu C, Guo K, Huang C, Mo L. Prognostic role of red blood cell distribution width in patients with sepsis: a systematic review and metaanalysis. BMC Immunol. 2020;21(1):40.

14. Ozdogan HK, Karateke F, Ozyazici S, Ozdogan M, Ozaltun P, Kuvvetli A, Gokler C, Ersoy Z. The predictive value of red cell distribution width levels on mortality in intensive care patients with community-acquired intraabdominal sepsis. Ulus Travma Acil Cerrahi Derg. 2015;21(5):352-7.

15. Uffen JW, Oomen P, de Regt M, Oosterheert JJ, Kaasjager K. The prognostic value of red blood cell distribution width in patients with suspected infection in the emergency department. BMC Emerg Med. 2019;19(1):76.

16. Ghimire R, Shakya YM, Shrestha TM, Neupane RP. The utility of red cell distribution width to predict mortality of septic patients in a tertiary hospital of Nepal. BMC Emerg Med. 2020;20(1):43.

17. Scharte M, Fink MP. Red blood cell physiology in critical illness. Crit Care Med. 2003;31(12 Suppl):S651-657.

18. Kim S, Lee K, Kim I, Jung S, Kim MJ. Red cell distribution width and early mortality in elderly patients with severe sepsis and septic shock. Clin Exp Emerg Med. 2015;2(3):155-61.

19. Yčas J, Horrow J, Horne B. Persistent increase in red cell size distribution width after acute diseases: A biomarker of hypoxemia? Clin Chim Acta. 2015:448:107-17.

20. Mani S, Ozdas A, Aliferis C, Varol HA, Chen Q, Carnevale R, Chen Y, Romano-Keeler J, Nian H, Weitkamp JH. Medical decision support using machine learning for early detection of late-onset neonatal sepsis. J Am Med Inform Assoc. 2014:21(2):326-36.

21. Juncal VR, Neto LAD, Camelier AA, Messeder OHC, Farias A. Clinical impact of sepsis at admission to the ICU of a private hospital in Salvador Brazil. J Bras Pneumol. 2011;37(1):85-92.

22. Flanagan L, Choi C, Lemdani M, Shah A, Parray A, Sukyte-Raube D, Fang C, Baredes S, Eloy J. Complication risk in ventral skull base surgery based on preoperative hematocrit. Laryngoscope. 2021;9:8.

23. Zulastri M, Hafidz M, Ismail M, Zuhdi A. Hematocrit change as a predictor of readmission for decompensated heart failure: a retrospective single centre study. Rev Cardiovasc Med. 2021:22(2):505-12.

24. Turcato G, Zaboli A, Ciccariello L, Pfeifer N. Estimated plasma volume status (ePVS) could be an easy-to-use clinical tool to determine the risk of sepsis or death in patients with fever. J Crit Care. 2020;58:106-12.
25. Jansma G, de Lange F, Kingma W, Vellinga N, Koopmans M, Kuiper M, Boerma E. "Sepsis-related anemia" is absent at hospital presentation; a retrospective cohort analysis. BMC Anesthesiol. 2015;15:55

26. Jiang $Y$, Jiang FQ, Kong F, An MM, Jin BB, Cao D, Gong P. Inflammatory anemia-associated parameters are related to 28-day mortality in patients with sepsis admitted to the ICU: a preliminary observational study. Ann Intensive Care. 2019;9(1):67.

27. Elshinawy M, Kamal M, Nazir H, Khater D, Hassan R, Elkinany H, Wali Y. Sepsis-related anemia in a pediatric intensive care unit: transfusionassociated outcomes. Transfusion. 2020;60(Suppl 1):S4-9.

\section{Publisher's Note}

Springer Nature remains neutral with regard to jurisdictional claims in published maps and institutional affiliations.
Ready to submit your research? Choose BMC and benefit from:

- fast, convenient online submission

- thorough peer review by experienced researchers in your field

- rapid publication on acceptance

- support for research data, including large and complex data types

- gold Open Access which fosters wider collaboration and increased citations

- maximum visibility for your research: over $100 \mathrm{M}$ website views per year

At BMC, research is always in progress.

Learn more biomedcentral.com/submissions 